NBER WORKING PAPER SERIES

WHAT DOES FINANCIAL LITERACY TRAINING TEACH US?

\author{
Bruce Ian Carlin \\ David T. Robinson \\ Working Paper 16271 \\ http://www.nber.org/papers/w16271 \\ NATIONAL BUREAU OF ECONOMIC RESEARCH \\ 1050 Massachusetts Avenue \\ Cambridge, MA 02138 \\ August 2010
}

The authors would like to thank Doug Bernheim, Annamaria Lusardi, John Lynch, and colleagues at Junior Achievement of Southern California for for helpful discussions throughout the project. This work was conducted in compliance with IRB human subject guidelines and was approved by the IRBs at Duke and UCLA. Dan Blanchette provided excellent research assistance. Seminar participants at Vanderbilt and Duke provided helpful feedback. Any errors are the authors' responsibility. The views expressed herein are those of the authors and do not necessarily reflect the views of the National Bureau of Economic Research.

NBER working papers are circulated for discussion and comment purposes. They have not been peerreviewed or been subject to the review by the NBER Board of Directors that accompanies official NBER publications.

(C) 2010 by Bruce Ian Carlin and David T. Robinson. All rights reserved. Short sections of text, not to exceed two paragraphs, may be quoted without explicit permission provided that full credit, including (C) notice, is given to the source. 
What Does Financial Literacy Training Teach Us?

Bruce Ian Carlin and David T. Robinson

NBER Working Paper No. 16271

August 2010

JEL No. A21,G18,H52

\begin{abstract}
$\underline{\text { ABSTRACT }}$
This paper uses a quasi natural experiment to explore how financial education changes savings, investment, and consumer behavior. We use data from a Junior Achievement Finance Park to measure the effect of a financial literacy program on students who are assigned fictitious life situations and asked to create household budgets for these roles. The treatment effects of the financial literacy program are strong. Students who experienced training were somewhat better at making current-cost/current-benefit tradeoff decisions (spending more today versus spending less today). But the tendency to try to save more today often led them to make poor choices when they faced tradeoffs between current-costs and future-benefits today (i.e., when spending more today is cheaper in present value terms). Most importantly, students who had attended training showed greater up-take of decision support that was offered in the park. This indicates that decision support and financial literacy training are complements, not substitutes.
\end{abstract}

Bruce Ian Carlin

Anderson Graduate School of Management

UCLA

110 Westwood Plaza, Suite C519

Los Angeles, CA 90095-1481

and NBER

bruce.carlin@anderson.ucla.edu

David T. Robinson

Fuqua School of Business

Duke University

One Towerview Drive

Durham, NC 27708

and NBER

davidr@duke.edu 


\title{
What Does Financial Literacy Training Teach Us?
}

\author{
BRUCE IAN CARLIN and DAVID T. ROBINSON*
}

August 3, 2010

\begin{abstract}
This paper uses a quasi natural experiment to explore how financial education changes savings, investment, and consumer behavior. We use data from a Junior Achievement Finance Park to measure the effect of a financial literacy program on students who are assigned fictitious life situations and asked to create household budgets for these roles. The treatment effects of the financial literacy program are strong. Students who experienced training were somewhat better at making current-cost/current-benefit tradeoff decisions (spending more today versus spending less today). But the tendency to try to save more today often led them to make poor choices when they faced tradeoffs between current-costs and future-benefits today (i.e., when spending more today is cheaper in present value terms). Most importantly, students who had attended training showed greater up-take of decision support that was offered in the park. This indicates that decision support and financial literacy training are complements, not substitutes.
\end{abstract}

\section{Introduction}

Financial literacy is defined as "the ability of people to make financial decisions in their own best short- and long-term interests" (Mandell, 2008). Unfortunately, this skill is in short supply in the United States. Many retirement-age adults lack the financial literacy to understand the basic features of their retirement plans (Lusardi and Mitchell, 2009). In a 2003 Survey by NASD, only $35 \%$ of respondents could answer better than 7 of 10 basic financial literacy questions - many respondents believed, for example, that stock market losses were insured (Associated Press, 2003). Around half of all high-school students surveyed by Jump\$tart.org thought that either the sales tax was set nationally at $6 \%$, or that the government deducted it from one's paycheck. (In fact, neither are true.)

Indeed, consumer financial literacy has been at the center of current debate concerning the causes and catalysts of the recent financial crisis. Many home owners did not appreciate the variable-rate clauses in their mortgages and their explicit exposure to interest rate risk; this led to a rash of defaults and foreclosures. At the same time, many individuals failed to appreciate the

\footnotetext{
* Bruce Carlin is from the University of California at Los Angeles; David Robinson is from Duke University. The authors would like to thank Doug Bernheim, Annamaria Lusardi, John Lynch, and colleagues at Junior Achievement of Southern California for for helpful discussions throughout the project. This work was conducted in compliance with IRB human subject guidelines and was approved by the IRBs at Duke and UCLA. Dan Blanchette provided excellent research assistance. Seminar participants at Vanderbilt and Duke provided helpful feedback. Any errors are the authors' responsibility.
} 
fees and interest rate schedules used commonly in credit cards, which exacerbated the amount of household debt and number of personal defaults in the United States. ${ }^{1}$

Finding the best approach to improving financial literacy is a hotly debated issue in both policy and academic circles, especially in light of the newly created Consumer Financial Protection Bureau. There are essentially three schools of thought. Some argue that providing better base education will improve welfare (e.g., Mandell, 2009; Bernheim and Garrett, 2003; Bernheim, Garrett, and Maki, 2001). But the evidence here is mixed. ${ }^{2}$ Thus, others stress timely decision support. For example, Bertrand and Morse (2009) show that timely, salient information about the true costs of payday loans causes people to frame their decisions more broadly and consequently take-up fewer loans. Lynch (2009) argues that timely decision support-apprising consumers of the consequences of various mortgage options before they choose a home - is preferable to increased disclosure in retail mortgage transactions. A third school of thought promotes libertarian paternalism; that is, nudging consumers in the right direction by judiciously choosing default options, thereby limiting the harm that arises from the failure to make an informed choice (Thaler and Sunstein, 2003; Choi, Madrian, Laibson, and Metrick, 2004).

In light of this debate, this paper studies the efficacy of education in a novel way. We make use of a pseudo-randomized, natural field experiment that occurred in the context of a financial literacy curriculum taught to 13-19 year-old students through the Junior Achievement Program of Southern California. The curriculum included training in credit card management, taxes, budgeting, and simple investments. Students are explicitly encouraged to plan for their future, to set aside money from each paycheck to save for the future, and to avoid reliance on credit cards. Of course, we do not claim that these are optimal heuristics or habits to develop. Rather, we simply use the training as it is to test whether the curriculum affected their behavior. Furthermore, as will become clear, we are not able to measure the effects of these behavioral changes on overall economic welfare.

Following the classroom training, students went to a "Finance Park" at the Junior Achievement headquarters. ${ }^{3}$ Each student at the park was randomly assigned a fictitious adult identity, including a monthly income level, a marital status, and a number of dependents (and ages, if applicable). The park itself consists of a number of kiosks where students can make everyday consumer finance-

\footnotetext{
${ }^{1}$ See Campbell (2006) for an extended discussion of many of these issues.

${ }^{2}$ Cole and Shastry (2009) show, for example, that financial literacy education does not impact behavior in a very large sample based on Census data.

${ }^{3}$ To view a video of the finance park, please visit the website http://www.jasocal.org/s/1019/start.aspx and click on the "Finance Park" link.
} 
related decisions, such as what type of insurance to buy, how much to save, whether to buy a cell phone, buying sports equipment, dining at restaurants, and the like. Students were asked to make a personal budget based on their character's monthly income, making decisions in each category while still operating within the budget. For example, a 17-year old high school student might be asked to make the financial decisions that a 28-year old, single, mother of two might face as she took a limited budget and allocated it between housing, clothes, utilities, car expenses, education, and recreation.

One might reasonably wonder whether the students took the role-playing seriously. There is ample evidence that, indeed, they did. The statistical analysis of their behavior shows that they played according to the roles they were assigned: wealthier characters spent more on leisure, characters with larger fictitious families secured bigger dwellings, cut back on luxury items, and spent more on clothing and insurance. Interviews with administrators and employees at the Finance Park uniformly indicate that students enjoy the experience and take it seriously. This is also echoed in the student testimonials that we examined, which were contained in the efficacy evaluations of the Finance Park.

While most students who went through the park received 19 hours of classroom instruction on personal financial management (these are "Finance Park" students), a subset of students did not (these are "Budget Challenge" students). They simply went through the park with no prior in-class training. Most schools either sent Finance Park students exclusively, or Budget Challenge exclusively, but not both. In light of this, one possible specification strategy could be simply to specify a dummy variable for curriculum exposure (Finance Park vs. Budget Challenge) and then study the choices that students made in the park across different schools. However, differences in school demographics are large; these would confound the treatment effect with variation in demographics, family background, grade level, and classroom performance. In particular, because parental wealth and education levels have been shown to predict student financial literacy (Lusardi, Mitchell and Curto, 2010; Lusardi and Mitchell, 2007; Lusardi, 2008), such a specification is likely to under-estimate the effect of the financial literacy program.

Instead, our identification strategy rests on two distinct populations of students. The first is a small group of students who went to the park twice: once before and once again after completing the classroom curriculum. This group, although severely limited in size (only 125 students in total, of whom 20 attended twice) provides the cleanest identification of the treatment effect associated with the curriculum, since nearly everything else is held constant. The second group comes from a 
set of schools that sent both trained and untrained students to the park. With the second group, we can include school fixed effects and compare the within-school performance differential associated with financial literacy training.

The data clearly demonstrate the efficacy of the training program. This is easiest to see in the small group that went through twice; here, the post-treatment group showed profoundly greater understanding of the financial issues they faced. Their completion rates were higher, they saved more, and they spent less on immediate gratification items such as clothing. These behaviors are consistent with the lessons offered in the curriculum they received. One simple explanation for this is that the students had been exposed to the park before; however, as we discuss in greater detail below, this is unlikely to drive the result. First, the visits were twelve weeks apart. Second, much of the students' experience in the park is driven by the random assignment of fictitious identities, and the repeating students were allocated different identities, jobs, budgets, family sizes, and home repair budgets on their two visits. Thus, the results from within-class exposure to the financial literacy training speak to the effectiveness of financial literacy training.

In the broader sample, students who received classroom financial literacy training made a range of choices that are consistent with delaying immediate gratification to increase overall wealth. For example, they chose to make larger monthly payments on home-improvement installment plans, thereby lowering the present-value of the interest costs they incurred.

Nevertheless, in some situations, the Finance Park students systematically displayed a bias towards choices that were costlier in the long-term but involved less monthly out-of-pocket cost. One important example is in making health care choices. Students in the park were presented with a range of health care options, with varying degrees of coverage corresponding to different levels of monthly premia. Plans that offered low monthly premia were more likely to be chosen by FP students, even though these plans exposed the participants to extensive out-of-pocket costs in the event that medical care would be needed.

The availability of timely decision support is the key to the seeming inconsistency between prudent financial planning with regard to financing home improvement and imprudent financial planning with regard to health insurance. The Finance Park is staffed with volunteers who provide information and answer questions about the budget choices the students face. For home improvement decisions, attendants nudge students toward amortizing their packages more quickly, paying more today but facing lower overall interest payments. The up-take of this advice is higher for students with training than without. When health care choices are made, the attendant clarifies 
relevant concepts such as co-pays and premia, but does not nudge students in any particular direction. Without the nudge, literacy-trained students spend less today on insurance plans, but this exposes them to greater expected costs in the future. Thus, the financial literacy training tuned the students' ears to actively guided decision support, but does not equip them to conduct a similar analysis by themselves.

There are two central messages that emerge from our analysis. First, financial literacy can indeed be taught, but with important limitations. Trained students in many cases adopted the decision-making that the program stressed, but often had difficulty extrapolating the underlying principles to new settings, and as a result made choices that were in some sense contrary to the spirit of the instruction they received. ${ }^{4}$

The second lesson, and perhaps the more important one, is that education and timely decision support are not distinct channels for improving consumer financial decision-making. They interact. Decision support is better utilized among the group that has received financial literacy training. Timely decision support and financial literacy training are complements, not substitutes.

These findings make a number of contributions to current debates on financial literacy, consumer financial protection, health care and retirement savings. One key contribution lies in the structure of our research design. Most evaluations of curriculum efficacy are based on comparisons of pre-course and post-course test scores. While certainly valuable in its own right, this research methodology is particularly problematic for financial literacy, where the real test of knowledge comes from understanding how behavior changes. Our work thus complements existing work that uses staggered introduction of state-level mandatory financial literacy curricula to measure the effectiveness of financial education (see Cole and Shastry (2009) or Bernheim, Garrett and Maki (2001) for prominent examples). The outcomes in question in these studies, however, are often much coarser because they are measured much further from the point of education than our measures.

Another contribution is to illustrate the unintended consequences of financial literacy training. In our setting, while literacy training improved many of the choices made by the students, it also created confusion between saving money today and making more economical choices in present value terms.

The remainder of the paper is structured as follows. We begin by describing the details of

\footnotetext{
${ }^{4}$ Difficulty in extrapolating beyond the scenarios used to illustrate educational principles is discussed in the educational psychology literature. See, for example, Thompson, Gentner and Lowenstein (2000) or Gentner, Lowenstein and Thompson (2003).
} 
the Junior Achievement Finance Park, since these details are so critical to our analysis. This is contained in Section II. In Section III, we describe the school demographics underlying the data that we obtained from the Finance Park, and the identification strategies that we use in greater detail. Section IV presents our main findings on the efficacy of the training program. Section V extends these basic results to explore the interaction between exposure to in-class training and exposure to in-park decision support. We conclude in Section VI by discussing how our findings inform ongoing discussions among academics and policy makers about the ways to increase literacy and sophistication in the financial marketplace.

\section{The Junior Achievement Finance Park}

Junior Achievement (JA) was founded in 1919 with a mission to educate young people about business, economics, and free enterprise through hands-on experiences. It is a global organization, teaching more than 9 million students in 108 countries.

Junior Achievement appears to be successful. A 1994-95 study on JA's educational impact by the Western Institute of Research and Evaluation found that elementary school JA students showed greater comprehension of economic principles than a comparison group of students who had not enrolled in JA. Among 6th graders, JA students scored 27\% higher than non-participants in basic economic understanding. On the high school level, a 1992 study by the Formative Evaluation Research Association found that JA students significantly surpassed their peers in the Test for Economic Literacy. ${ }^{5}$

Although Junior Achievement has a number of initiatives that are tailored to different age groups, our sole emphasis in this paper is the Finance Park at Junior Achievement. The JA Finance Park offers students personal financial management and career exploration through classroom instruction and active participation in a simulated finance setting. The curriculum includes 19 hours of didactic (in-classroom) study of financial institutions, taxes, credit, and personal budgeting. The educational experience culminates in an all-day visit to JA Finance Park, which is a simulated experience where students get a hands-on experience in personal budgeting.

In the curriculum, students receive two primary messages: 1) be wary of the costs of credit; 2) use savings to plan for the future. Students participate in many concrete exercises that solidify these ideas. For example, they are given the costs of consumption goods with and without financing

\footnotetext{
${ }^{5}$ This section is based on material obtained from Junior Achievement. For more information regarding Junior Achievement, please visit the website http://www.jasocal.org.
} 
(e.g., Gasoline: $\$ 35$ cash, $\$ 42$ credit). They are shown that money grows in a savings account and how this changes with the interest rate and length of time. They are given budget example exercises where the stated goal is to save $20 \%$ of their net monthly income (e.g., $\$ 300$ savings for an income of $\$ 1,500){ }^{6}$

The Finance Park experience also appears to be successful. A 2008 program study showed that both JA and non-JA students improved their financial literacy as measured by pre- and post-test questionnaires (JA Finance Park Final Report, 2008). A 2006 study of middle-school students arrived at the same conclusion (Finance Park Middle Grades Pilot Program, Final Report 2006). While both of these studies show that students' factual background increased as a result of the training, neither study evaluated the effect of the training on the choices participants made while in the park. As such, it is clear that students do learn, but remains an open question how the education affected their students' decisions.

During the Finance Park simulation, students are randomly given an identity, which includes their age, employment, marital status, number of dependents, personal income, and taxes. Students report to their place of employment, which is one of the 18 kiosks at the park where financial decisions are made. Each kiosk is staffed by a volunteer, who assists them. They begin by calculating their Net Monthly Income (NMI) which is their monthly take-home income net of taxes, Medicare, and Social Security contributions. Following this, students are asked to create a personal budget, which includes housing choices, health insurance, credit management, recreation, investment in continuing education, charity, cell phone plan, and home improvement. Then students travel to each kiosk around the park, entering their choices in the computer, with the specific goal of creating a balanced budget that is responsible and represents their preferences.

The data that we use in the present analysis are the completed budget review statements that reflect the choices the students made while engaged in the role play. Table 1 reports the frequency distribution of participants according to income, marital status, and family size. The age of the profile characters ranged from 25-35 years of age, with a median of 30. The annual gross income ranged from $\$ 20,000$ to $\$ 65,000$ per annum. To put the income numbers in perspective, data from the U.S. Census indicate that the median household income for metropolitan Los Angeles in 2008 was around $\$ 55,000$ per year. In contrast the median household income in zip-code 90222 (a zip code in the Compton area of South Central Los Angeles) was only around $\$ 29,500$ for 2000 .

\footnotetext{
${ }^{6}$ Examples are taken from the JA Finance Park Student Workbook, which is available upon request.
} 
... Table 1 about here ...

As Table 1 shows, students are about equally split between married and unmarried, and between having children and not having children. Those students whose characters have children are allocated one or two children about equally. These are scattered more or less uniformly across the income distribution, so that there is a fair representation of characters across the income, marital status and family status distribution.

Table 2 reports regressions relating expenditure at each of 18 kiosks to the fictitious characteristics. Before we discuss the regression results, it is useful to describe each of the kiosks in detail.

Bank of America is the kiosk where students pay for the housing choices they make. Students make choices that range from cozy apartments to larger houses, although no distinction is made between renting and owning. Kiosks 2, 3, and 5 (Gas, SoCal Edison, and Water/Sewer/Trash, respectively) are choices that are directly impacted by the housing choice they make and their family size. In particular, their expenditures at the Gas Company and SoCal Edison were linked to the size of their dwelling, while their Water/Sewer/Trash expenditure was linked to the number of people in their family. The Phone kiosk (\#4) allows students to choose between a variety of phone packages. Some of these packages are based on land-line coverage, while a la carte cell phone plans are also offered.

The Toyota kiosk is where students make the automobile choice. The choice they make here, along with their housing choice, affect baseline amounts they will owe at the State Farm kiosk (\#10). The choices that they make for grocery and clothing are not based on household size, but rather on their preferences.

Kiosk \# 9, the Union Bank kiosk, is the place where students make savings decisions. There is a significant difference in the savings rate (savings as a percentage of net monthly income) based on whether students were exposed to training or not. This is examined more closely in Table 7.

Kiosk \#11 is where students make health insurance choices. Although there is no difference in the unconditional mean choice, this in part is a function of the fact that price masks important variation in the terms of care provided by the health insurance. We take this issue up in greater detail in Table 9 below.

The remaining kiosks allow students to take community college classes to further their education (kiosk \#12), to invest in home improvement (\#13), and to spend on a variety of leisure items like 
entertainment, sporting equipment and dining out (kiosks \#14-\#16, respectively). Students also gave a portion of their income to charity (kiosk \#17), which was discretionary within a prescribed range of choices. The final kiosk is one where students might face an unexpected financial outlay. If they had not budgeted sufficiently, this might cause them to have to go back and readjust their spending at other kiosks. Because we only observe the completed work sheets, we cannot observe how this impacts their choice.

Table 2 provides an analysis of spending patterns in the park based on the school demographics and profile characteristics that the students were asked to assume. The Junior Achievement staff indicate that, in general, students take their role-playing quite seriously and report that the experience was fun and eye-opening. These tables bear this out; they illustrate that students made choices in keeping with the roles they were assigned. For example, students whose characters were married and had children chose significantly more expensive housing. They also spent more on utilities and clothing, but less on automobiles. Consequently, they saved less.

\section{... Table 2 about here ...}

The structure of the home improvement kiosk (kiosk \#13) is important for our analysis. Students are randomly assigned an amount that they must spend in home improvement. Their choice is not home much to spend on home improvement, but rather how to finance it. As we discuss in detail below, this fact is important for our analysis because it affects the interpretation of the connection between financial literacy exposure and both the savings results and the home improvement results.

With the basic choices available to students laid out, and the relation between these choices and the demographics of both the roles they were assigned and the schools they came from in place, we now examine how exposure to financial literacy training affects their choices.

\section{School Demographics and Identification Strategies}

While the preceding section discussed the data in terms of the fictitious identities used in the park, it was silent on the underlying characteristics of the student populations who attend the park. In this section we explore actual student demographics. This allows us to lay out our identification strategy in greater detail.

Table 3 provides a snapshot of the schools that participated in the Finance Park in our sample period. The names of the schools have been masked to preserve the anonymity of the participating organizations. The column labelled "Math" is the proportion of students at the school who are 
at grade-level proficiency for mathematics. As the column indicates, many of these schools score poorly on this dimension. Many schools in our sample have fewer than 1 in 4 students at math grade level. The "Rank" column is a decile ranking of the schools API score. One is the lowest decile, ten is the highest. Thus, many of the schools have low overall rankings.

The remaining columns indicate that many of these schools also serve economically challenged communities. AVGPE is the average parental education level at the school: numbers here range from 1 (did not finish high school), 2 (high school, no college), 3 (attended college), 4 (completed college), and 5 (attended post-graduate school). The average indicate that with the clear exception of School W, most schools serve areas with very low levels of parental education. Similarly, FRPM is the fraction of students eligible for free and reduced price meals; since this statistic is tied to the poverty line, it indicates that average household wealth levels in the areas served are low. The columns under the District/School and Black/Hispanic headings indicate the proportion of students of black or hispanic origin, either in the school itself or on average in the district in which the school is located. The figures indicate that for the most part, the schools in our data serve heavily black and hispanic populations, even compared to the districts in which they operate.

The final columns indicate the number of students who successfully completed the park, and the number from each school that attended the financial literacy training course beforehand. ${ }^{7}$ The columns indicate that, with the exception of Schools $\mathrm{T}$ and $\mathrm{U}$, all other schools sent batches of students who either completely attended or completely did not attend the prior training.

... Table 3 about here...

In terms of establishing an appropriate strategy for identifying a treatment effect associated with exposure to the curriculum, Table 3 demonstrates two points. One is that there are pronounced differences in school demographics based on whether the school attended the park with or without the training. Thus, simply specifying a dummy for whether a student attended the finance park training and identifying this parameter cross-sectionally is unlikely to provide a good measure of the effects of the treatment, since it is muddied by the fact that students from better performing schools and less economically disadvantaged backgrounds were likely to have skipped the training. Given the evidence in Lusardi, Mitchell and Curto (2010) on the importance of parental education and financial literacy for predicting childhood financial literacy, this suggests that a cross-sectionally

\footnotetext{
${ }^{7}$ Table 6 is the only time in the paper that we make use of the fact that not all students successfully completed the worksheets at the park. See below.
} 
identified dummy variable for finance park training would severely underestimate the true effect of the financial literacy training on their behavior.

This fact can be seen more clearly in Table 4, which provides breakdowns of school characteristics according to whether the school in question participated in the financial literacy training (Finance Park) or simply attended the park (Budget Challenge). About the only observed similarity between the types of schools is the extent to which they serve hispanic students: otherwise, schools in the treatment group have higher rates of FRPM eligibility, lower parental education levels, are located in districts with larger black and hispanic populations, serve largely black students within those districts, and have lower test scores and graduation rates.

... Table 4 about here...

Instead, our identification strategy is based on two distinct subsamples of students. One subsample can be seen in Table 3: these are Schools T and U. Since these schools sent students with and without training, one strategy is to estimate the effect of training by including school fixed effects, thereby identifying the treatment effect through the variation in exposure within these schools. Even still, this is a within-school, not a within-class estimate: students from a given school who went through the park without prior training may well be older and/or from stronger performing classrooms than those who did not. As such, this estimate is not a pure treatment effect.

To obtain a cleaner measure of the treatment effect of the curriculum, we turn to a small set of students from a high school in LA who went through the program twice during the 2009-2010 academic year. ${ }^{8}$ These students attended the park, then took the curriculum, and then went through the park a second time. This group includes 81 students who attended in early February and 44 who attended in late April. All students attending in late April had completed the training, and none in February had received any training. Only 20 students attended both sessions. This group is small in size but gives us perhaps the cleanest measure of the pure treatment effect associated with the classroom training. For reasons that will become apparent below, this sample does not lend itself to the study of the interaction between training and decision support. Therefore, we rely heavily on both subsamples of students for most of our analysis.

\footnotetext{
${ }^{8}$ Confidentiality requirements prevent us from disclosing the name of the school. However, it is in the South LA area, and is approximately $52 \%$ black and $47 \%$ hispanic in student makeup. It has an API score of 1 , placing it in the lowest decile, and has around $2 \%$ of students at or above California state-level math proficiency.
} 


\section{Main Results}

This section explores the basic question of whether the curriculum affected the behavior of the students who were exposed to it. This question has a simple answer, which can be seen from Table 5 .

... Table 5 about here ...

Panel A of Table 5 reports differences in behavior before and after the curriculum exposure for the small group. The most striking sign of the efficacy of the training program is the completion rate. Before the training, only one student was able to complete the park (i.e., able to go through and produce a balanced budget). After the training, over half the students did. This difference is highly statistically significant.

There are also pronounced differences in the allocation decisions that students made in the park. The remainder of Panel A reports percentages allocated to each kiosk. Since the pretreatment completion rate was virtually zero, it is misleading to scale the allocations at each kiosk by the total net monthly income in the pre-treatment group. This would lead us to conclude that the post-treatment sample spent larger amounts on everything. Instead, whenever a student did not complete the park, we scale the amount spent at a kiosk by the total amount spent across all kiosks, rather than by net monthly income. ${ }^{9}$

After receiving the classroom training, students spent more on housing, more on cars, and more on insurance. This reflects a greater understanding of the budget-making process. In addition, the savings rate in the post-treatment sample is almost four times that of the pre-treatment sample. They spent significantly less on clothing. Taking the clothing and savings choices together, Panel A indicates that the post-treatment students favored delayed over immediate gratification in their decision-making.

One simple explanation for these results, especially the results on higher completion rates, is that the students were visiting the park a second time, and were therefore already familiar with the protocol. There are a number of reasons that this is unlikely to drive the results. First, twelve weeks passed between the first and second visits to the park. If the visits were spaced more closely, there would be a greater concern that repetition were driving our results. But more importantly, each student's park experience is influenced by the random identity they were assigned. Recall that

\footnotetext{
${ }^{9}$ We have also made comparisons only among the incomplete records as a robustness check. This produces similar findings to those reported in Panel A.
} 
students report to the kiosk that represents their "place of employment" to plan their budgets. No students reported to the same employer on subsequent visits. Moreover, no students had the same family structure on both visits, nor did they have the same income or home repair budget. This variation in identity, combined with the time between the park experiences, works against this effect being attributable purely to repetition.

One way to gauge the magnitude of the treatment effect is to compare the within-class estimate with the across-school estimate, which is reported in Panel B. This panel shows a considerably more muted difference between exposure and non-exposure groups. The "BC" column of Panel $\mathrm{B}$ reports the average percentages for the group of Budget Challenge students; these are mostly those that came from schools that did not adopt the curriculum and instead only went to the park. As Table 3 above shows, these schools are systematically higher performing schools that serve less economically challenged areas than the schools that adopted the Finance Park training curriculum. Across the whole sample, the completion rates are roughly the same, and many of the choices are either not different between the two groups or else go in the opposite direction from that indicated in Panel A. This points to the fact that the curriculum acts as a substitute to the skills that are present in the better performing schools.

Nevertheless, more evidence indicating the effectiveness of the financial literacy training can be found in Table 6, which examines completion rates by training status across the entire sample. Here the finance park dummy is identified by variation in the two schools that sent students to the park both with and without training. The larger sample size, coupled with the higher completion rates in the Budget Challenge group make the estimation feasible, but the parameter itself also captures within school variation in grade-level and achievement that probably biases downward our estimate of the treatment effect.

... Table 6 about here ...

This table illustrates that holding constant average differences attributable to school effects, students with literacy training were significantly more likely to complete the budget reviews. This means that they were able to turn in a completed, balanced budget within the time frame allotted to them more often than the untreated group. The point estimate suggests that this effect is economically large, around $35 \%$.

Table 7 shows how the financial literacy training affected the students' choices. The broad takeaway from this table is that the students who received the financial literacy training were 
more attune to making choices that can be described as investments in the future and delaying gratification. For example, students in the treatment group spent more to pay off their debt obligations on their home improvement. Nevertheless, the savings result goes in the opposite direction to that reported in Panel A of Table 5, which only focuses on the narrow sample of students that went through the park before and after training. This indicates the strength of countervailing demographic effects working against the measurement of the treatment effect.

... Table 7 about here ...

The fact that students in the treatment group saved less is in part a reflection of a mechanical adding-up constraint imposed by the structure of the exercise. Because students in the treatment group were more likely to amortize their home improvement packages more quickly to economize on interest expenses, they faced larger monthly home improvement expenditures (this can be seen from the loading on the finance park dummy in Column (13) of Table 7). Comparing the finance park coefficients in Column (13) and Column (9) indicates that the home improvement allocation alone is not sufficient to explain the entire difference in savings rate; however, it is important to bear in mind this fact when considering the difference in savings rates across the treated and untreated groups.

In summary, this section illustrates that the financial literacy training had an effect on the students who were exposed to it. Students who were exposed to training completed the program faster, and they made many choices that are consistent with delaying immediate gratification in favor of investing in longer-term outcomes. Our results here are not unambiguous, however. Indeed, previous literature has found mixed results on the effectiveness of financial literacy training.

\section{Are Education and Decision Support Complements or Substitutes?}

While the previous section focused primarily on the effectiveness of the training in terms of the choices made by treated students, this section focuses on a different question. Namely, are education and decision support complements or substitutes? This question is important because implicit in most policy analyses of consumer literacy is the assumption that education replaces

decision support, or vice versa. Indeed, in this section we present evidence suggesting that one of the primary benefits of education may be to increase the up-take of timely decision support.

To do this we exploit some specific features of the park experience that students face. In particular, students purchase a home improvement package on credit, and then choose an amortization 
schedule for that credit plan. They can choose to make lower monthly payments, but by doing so they face higher interest costs over the life of the credit plan. Or they can choose to make larger payments, leaving them less money each month, but saving money over the life cycle of the credit plan.

... Table 8 about here ...

Table 8 presents these findings in two ways. In the first three columns, the dependent variable is the log of the ratio of interest cost to total credit package size. The second three columns report regressions of log ratio of monthly payment to total credit plan size. Columns (1) and (4) have school fixed effects and $\log$ (net monthly income). Columns (2) and (5) replace log(net monthly income) with income fixed effects and maintain the school fixed effects. Columns (3) and (6) drop the school fixed effects and replace them with school characteristics. Focusing, therefore, on the first two columns, we see that the financial literacy exposure reduces the interest payments by about $6-10 \%$ of the total credit plan size. Columns (3) and (4) turn this result around by showing that the finance training raises the monthly payout on the credit plan by about $5 \%-8 \%$.

Thus, the results of Table 8 indicate that there was a significant interaction between prior exposure to financial literacy training and the presentation of timely advice about financial management. Attendants in the park frequently reminded students to consider paying off their debt earlier. However, even though the students who did not receive financial literacy training prior to the park experience heard the same advice, many did not take it. One interpretation is that the prior literacy training primes people to act on advice, or that the advice itself recalls past training that people have received.

To explore this idea further, we are able to identify a different situation in the park experience that offered a similar financial tradeoff but without similar decision support: the choice of health insurance. When students make their health insurance choice, they can choose between three plans with fairly low premia and three plans with high premia. The low premia plans vary in cost and services covered, but they all share a common feature: they require the policy holder to pay a percentage of the total bill as a co-pay. The higher premia plans offer fixed-rate copays. In some sense, the choice faced here mirrors the choice faced at the home improvement kiosk, because in both settings, students must choose between paying more today for lower payouts in the future, or paying less today but more in the long-run. To be sure, there are important differences in the types of decisions students are being asked to make. The choices vary both in terms of where they 
sit in a student's locus of control (ample research in psychology indicates that people understate the probabilities of bad outcomes when they think they can exert influence over those outcomes). They also have important risk differences: in the case of home improvement, there is no uncertainty surrounding future payments. In the case of health insurance, students are exposing themselves to potential income volatility by adopting percentage-payment plans.

Importantly, the two kiosks differ in terms of the structure of decision support that is offered. Attendants actively prescribe one type of choice over another at the home improvement kiosk. Attendants at the health insurance kiosk do not advocate for one package or another, but instead simply explains concepts such as co-pays, premia, etc. Drawing on this difference allows us to consider the interaction between decision support and financial literacy exposure.

... Table 9 about here ...

The results are presented in Table 9. The first three columns examine whether someone is under-insured. We determine this by comparing the character's family size to the reported cost of the plan they choose to see if they chose a policy that only covered a single person when their profile character was married or had children. From the profile characteristics, it is clear that this occurred most often among people who were married without children. The presence of children made this much less likely. One reasonable explanation here is that the respondent assumed that their profile character's fictitious spouse had their own insurance somewhere else.

The second three columns examine a dependent variable that is a dummy for whether the respondent chose a more expensive plan that offered flat-fee co-payments. The results are striking. Students with financial literacy exposure were much less likely to choose these plans. In doing so, they economized on monthly premia, but faced potentially higher out-of-pocket costs, and indeed, potentially more volatile income.

It is important to stress that the variation in the park experience that we exploit does not constitute a randomized field trial of the effect of varied decision support. Such a research design was not available to us; we simply made use of existing variation in the data. Nevertheless, the findings in this section are important for the ongoing academic and policy discussions about the relative merits of alternative strategies for improving consumer financial decision-making. In concurrent work, Bertrand and Morse (2009) conduct a randomized trial at payday lenders where they provide timely information to would-be borrowers about the true costs of accessing payday lenders. They find that apprising would-be borrowers of the total cost causes them to think about their decision 
in a broader decision frame, and consequently makes it less likely that they borrow from the payday lender. Our work suggests in turn that the ability to make use of the information being provided by the Bertrand/Morse intervention would be increased by augmenting the general financial education made available to such borrowers. In short, education and decision support are complements, not substitutes.

\section{Discussion and Conclusion}

This paper uses a pseudo-randomized natural experiment in high-school and middle-school financial literacy training to study how training affects the choices that people make. In our study, high-school and middle-school age students in the Los Angeles area were randomly assigned fictitious adult identities, and then were asked to role-play in an environment where they had to make the types of financial decisions that are faced by, say, a single mother with two children making around $\$ 30,000$ per year, or someone with median income family in LA, but with no children.

Although the assignment of adult roles is random in our data, the students' access to literacy training is not. Our study is only pseudo-randomized because we do not control the assignment of students to treatment and control groups: instead, we have to rely on the fact that some schools engaged in financial literacy training to varying degrees. We identify the main effect of financial literacy training by looking at two types of variation. The first is within-class variation among a group of students who attended the park both before and after receiving financial literacy training. The second is within-school variation in exposure to training in statistical models that include both school fixed effects as well as standard error corrections that account for dependence across individuals participating in the role-playing exercise at the same time.

In our setting, financial literacy training works. One measure of this is simply differential rates of task completion: students in the treatment group are about $35 \%$ more likely to complete the budget balancing exercise that they are given than those in the non-treatment group. Moreover, there are pronounced differences between the treatment and control groups when we look across the various kiosks at which fictitious financial decisions were made. But how did the financial literacy training change their behavior? And how did it work? What does it teach us to do differently?

Our results suggest that financial literacy training teaches us at least two things. On the one hand, we find some evidence that students who were exposed to literacy training made better financial decisions. Comparing the same class of students before and after training clearly indicates greater financial sophistication and higher savings rates after the training program. In the broader 
sample of students, those exposed to training saved less on average, but this most likely results from measurement problems associated with counterselection. Even in this group, most of the lower average savings rate comes from a lower elasticity of savings with respect to income. Holding constant the income elasticity, students in the treatment group save about the same, or a little more than others.

The second thing that financial literacy training teaches us is to make better use of the information around us. In our study, exposure to financial literacy training increased the up-take of timely advice. All students in our study were exposed to decision support surrounding the benefits of paying off their credit installment plans early; however, students who were exposed to literacy training were significantly more likely to act on this advice. In a contrasting setting, in which students faced a similar decision with respect to health insurance in the absence clear-cut advice, the students with exposure to financial literacy training avoided high monthly premium insurance plans, even though these plans might have offered lower out of pocket costs down the road.

Interpreting the behavior coming out of these contrasting settings requires caution. First, the advice being offered was of a particular form: in both settings, the choice that conserved cash-flow had a long-term cost, and the advice apprised the students of the cost. In the setting with decision support, students moved away from the default towards plans with lower present value costs but higher out-of-pocket costs. Generalizing to different information/default structures with different sets of behavioral biases embedded in them requires care. Second, not all advice is good advice. Would the treated group have seen through bogus advice? Perhaps not. Evidence from a NASD investor fraud survey (NASD, 2006) showed that senior citizens with more financial literacy were more likely, not less likely, to be victims of fraud. Ours is the first evidence that directly speaks to the interaction of financial education and timely decision support as alternatives for improving consumer financial decision-making. Hopefully it is not the last. 


\section{References}

[1] Associated Press (2003). "Survey Reveals Misinformed Investors". Associated Press, December $2,2003$.

[2] Bernheim, B. Douglas and Daniel M. Garrett (2003), "The effects of financial education in the workplace: evidence from a survey of households," Journal of Public Economics 87, 1487-1519.

[3] Bernheim, B. Douglas and Daniel M. Garrett and Dean Maki (2001), "Education and saving: The long-term effects of high school financial curriculum mandates," Journal of Public Economics 80, 435-465.

[4] Bertrand, Marianne, and Adair Morse (2009), Information Disclosure, Cognitive Biases and Payday Borrowing, working paper, University of Chicago.

[5] Campbell, John Y. (2006), "Household Finance," Journal of Finance, 61(4), 1553-1604.

[6] Choi, James, David Laibson, Brigitte Madrian and Andrew Metrick (2002). "Defined Contribution Pensions: Plan Rules, Participant Decisions, and the Path of Least Resistance," in Tax Policy and the Economy, James Poterba, ed., pp. 67-113, Volume 16, MIT Press

[7] Cole, Shawn and Gauri Kartini Shastry (2008), "If you are so smart, why aren't you rich? The effects of education, financial literacy, and cognitive ability on financial market participation," working paper, Harvard Business School and University of Virginia.

[8] Evaluation and Training Institute (2006), "Middle Grades Pilot Program: JA Finance Park Final Report"

[9] Evaluation and Training Institute (2008), "JA Finance Park Final Report"

[10] Gentner, Dedre, Jeffrey Lowenstein and Leigh Thompson (2003), "Learning and Transfer: A General Role for Analogical Encoding," Journal of Educational Psychology 95(2) 393-408.

[11] Lusardi, Annamaria, and Olivia S. Mitchell (2007). "Financial Literacy and Retirement Preparedness: Evidence and Implications for Financial Education." Business Economics, vol 42, number 1 . 
[12] Lusardi, Annamaria, Olivia S. Mitchell and Vilsa Curto (2008). "Financial Literacy Among the Young: Evidence and Implications for Consumer Policy." Working Paper, Harvard, Wharton, and Dartmouth.

[13] Lusardi, Annamaria (2008). Household Saving Behavior: The Role of Literacy, Information and Financial Education Programs, NBER Working Paper n. 13824.

[14] Lynch, Jr., John G., (2009) "Information Remedies, Choice Architecture, and Plain Vanilla Financial Products," working paper, Russell Sage Foundation.

[15] Mandell, Lewis (2008), "Teaching Young Dogs Old Tricks: The Effectiveness of Financial Literacy Intervention in Pre-High School Grades, chapter in Thomas A. Lucey and Kathleen S. Cooter (eds), Financial Literacy for Children and Youth Digitaltextbooks.biz.

[16] Mandell, Lewis (2009), "Results of the 2008 National Jump\$tart Coalition Survey of High School Seniors and College Students," working paper, University of Washington.

[17] NASD Investor Education Foundation (2006), "Investor Fraud Study: Final Report".

[18] Thaler, Richard H. and Cass R. Sunstein (2003), "Libertarian Paternalism." American Economic Review (Papers and Proceedings) 93(2) Fall: 175-179.

[19] Thompson, Leigh, Dedre Gentner and Jeffrey Lowenstein (2000), "Avoiding Missed Opportunities in Managerial Life: Analogical Training More Powerful than Individual Case Training," Organizational Behavior and Human Decision Processes 82(1), 60-75. 
Table 1: Profile Characteristics

This table presents the frequency distribution of income and family structure for all participants in our sample.

\begin{tabular}{|c|c|c|c|c|c|c|c|c|}
\hline \multirow{3}{*}{$\begin{array}{c}\text { Net } \\
\text { Monthly } \\
\text { Income }\end{array}$} & \multicolumn{4}{|c|}{ Unmarried } & \multicolumn{4}{|c|}{ Married } \\
\hline & \multicolumn{4}{|c|}{ \# of Children: } & \multicolumn{4}{|c|}{ \# of Children: } \\
\hline & Zero & One & Two & Total & Zero & One & Two & Total \\
\hline 1,580 & 53 & 44 & 21 & 118 & 14 & 28 & & 42 \\
\hline 1,911 & 71 & 29 & . & 100 & 22 & 22 & 15 & 59 \\
\hline 2,337 & 63 & 21 & 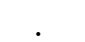 & 84 & 37 & 2 & 34 & 73 \\
\hline 2,764 & 25 & 17 & 15 & 57 & 60 & 23 & 9 & 92 \\
\hline 3,189 & 52 & . & . & 52 & 70 & 34 & 13 & 117 \\
\hline 3,635 & 84 & 24 & & 108 & . & 26 & 40 & 66 \\
\hline 3,829 & 13 & 39 & 53 & 105 & . & 13 & 39 & 52 \\
\hline 4,031 & 60 & & 4 & 64 & 48 & 41 & 22 & 111 \\
\hline 4,432 & 29 & . & 16 & 45 & 24 & 58 & 20 & 102 \\
\hline 4,873 & 12 & 36 & 3 & 51 & 36 & 20 & 57 & 113 \\
\hline
\end{tabular}


Table 2: Where the Money Went: School Characteristics

This table reports Tobit estimations in which each dependent variable is a spending category. School and wealth fixed effects are included, but suppressed. Standard errors are clustered at the school level. Bank of America is the kiosk associated with home purchase or rental decisions. The size of the home chosen has a direct impact on items 2, 3, and 5, which are gas, electricity, and municipal services, respectively. Item 4 is the choice of telephone package; this includes cell phones and different varieties of land-line packages. Toyota is the kiosk where they make a car purchase decision. Union Bank (kiosk \#9) is a savings account. State Farm is auto and property insurance, and the choice here is largely dictated by the choice in (1) and (6). Providence St. Joseph (kiosk \#11) is health insurance; participants can choose between six plans that vary in terms of the monthly premium and coverage levels (see Table 9). L.A. Valley College (kiosk \#12) is a community college where they can pay for courses that equip them with more marketable skills. Home improvement is mandatory, and is the monthly payment level associated with a home improvement plan they choose. Entertainment, Sport, and Dining out each represent opportunities to enjoy movies, sporting equipment purchases, or dining out. "Charity" reflects an amount they choose to donate to a local charity.

\begin{tabular}{|c|c|c|c|c|c|c|c|c|c|}
\hline & $\begin{array}{l}\mathrm{B} \text { of } \mathrm{A} \\
(1)\end{array}$ & $\begin{array}{c}\text { Gas Co. } \\
(2)\end{array}$ & $\begin{array}{l}\text { SoCal Ed } \\
(3)\end{array}$ & $\begin{array}{c}\text { Phone } \\
(4)\end{array}$ & $\begin{array}{c}\text { Util. } \\
(5)\end{array}$ & $\begin{array}{c}\text { Toyota } \\
(6)\end{array}$ & $\begin{array}{l}\text { Groc. } \\
(7)\end{array}$ & $\begin{array}{c}\text { Clothing } \\
(8)\end{array}$ & $\begin{array}{c}\text { Union Bank } \\
(9)\end{array}$ \\
\hline $\log (\mathrm{NMI})$ & $\begin{array}{c}-1.511^{* * *} \\
(0.095)\end{array}$ & $\begin{array}{c}-1.784^{* * *} \\
(0.044)\end{array}$ & $\begin{array}{c}-0.321^{* * *} \\
(0.056)\end{array}$ & $\begin{array}{l}-0.058 \\
(0.068)\end{array}$ & $\begin{array}{c}-2.371^{* * *} \\
(0.047)\end{array}$ & $\begin{array}{c}0.573^{* * *} \\
(0.091)\end{array}$ & $\begin{array}{c}0.913 * * * \\
(0.086)\end{array}$ & $\begin{array}{c}0.638^{* * *} \\
(0.124)\end{array}$ & $\begin{array}{c}1.868^{* * *} \\
(0.311)\end{array}$ \\
\hline Kids $==1$ & $\begin{array}{c}0.425^{* * *} \\
(0.061)\end{array}$ & $\begin{array}{c}0.134^{* * * *} \\
(0.025)\end{array}$ & $\begin{array}{l}-0.009 \\
(0.031)\end{array}$ & $\begin{array}{c}-0.139^{* *} \\
(0.056)\end{array}$ & $\begin{array}{c}0.542^{* * * *} \\
(0.021)\end{array}$ & $\begin{array}{c}-0.255^{* * *} \\
(0.060)\end{array}$ & $\begin{array}{l}-0.044 \\
(0.064)\end{array}$ & $\begin{array}{c}0.231^{* * * *} \\
(0.060)\end{array}$ & $\begin{array}{c}-0.621^{* * *} \\
(0.145)\end{array}$ \\
\hline Kids $==2$ & $\begin{array}{c}1.033^{* * *} \\
(0.116)\end{array}$ & $\begin{array}{c}0.266^{* * * *} \\
(0.024)\end{array}$ & $\begin{array}{c}0.113^{* *} \\
(0.044)\end{array}$ & $\begin{array}{c}-0.248^{* * *} \\
(0.070)\end{array}$ & $\begin{array}{c}0.734^{* * *} \\
(0.030)\end{array}$ & $\begin{array}{c}-0.400^{* * *} \\
(0.068)\end{array}$ & $\begin{array}{c}0.152 \\
(0.099)\end{array}$ & $\begin{array}{c}0.042 \\
(0.066)\end{array}$ & $\begin{array}{c}-0.676^{* * *} \\
(0.170)\end{array}$ \\
\hline Age & $\begin{array}{c}0.005 \\
(0.008)\end{array}$ & $\begin{array}{l}-0.003 \\
(0.003)\end{array}$ & $\begin{array}{c}0.013^{* * *} \\
(0.004)\end{array}$ & $\begin{array}{l}0.007 \\
(0.007)\end{array}$ & $\begin{array}{l}-0.000 \\
(0.004)\end{array}$ & $\begin{array}{l}-0.000 \\
(0.011)\end{array}$ & $\begin{array}{l}-0.011 \\
(0.009)\end{array}$ & $\begin{array}{l}-0.001 \\
(0.007)\end{array}$ & $\begin{array}{l}-0.012 \\
(0.017)\end{array}$ \\
\hline \multirow[t]{2}{*}{ Married } & $\begin{array}{c}0.210^{* * *} \\
(0.061) \\
\end{array}$ & $\begin{array}{l}0.032^{*} \\
(0.018) \\
\end{array}$ & $\begin{array}{c}0.118^{* * *} \\
(0.025) \\
\end{array}$ & $\begin{array}{c}0.035 \\
(0.065) \\
\end{array}$ & $\begin{array}{c}0.405^{* * *} \\
(0.014) \\
\end{array}$ & $\begin{array}{c}-0.091^{* *} \\
(0.045) \\
\end{array}$ & $\begin{array}{l}-0.002 \\
(0.064) \\
\end{array}$ & $\begin{array}{l}-0.064 \\
(0.060) \\
\end{array}$ & $\begin{array}{c}-0.341^{* *} \\
(0.165) \\
\end{array}$ \\
\hline & $\begin{array}{c}\text { State Farm } \\
(10)\end{array}$ & $\begin{array}{c}\text { Prov. St. Joe } \\
(11)\end{array}$ & $\begin{array}{l}\text { LA Coll. } \\
\quad(12)\end{array}$ & $\begin{array}{l}\text { Home Imp. } \\
\quad(13)\end{array}$ & $\begin{array}{c}\text { Entert. } \\
(14)\end{array}$ & $\begin{array}{c}\text { Sport } \\
(15)\end{array}$ & $\begin{array}{c}\text { Dine Out } \\
(16)\end{array}$ & $\begin{array}{c}\text { Charity } \\
\text { (17) }\end{array}$ & $\begin{array}{c}\text { Chance } \\
(18)\end{array}$ \\
\hline $\log (\mathrm{NMI})$ & $\begin{array}{c}-2.104^{* * *} \\
(0.041)\end{array}$ & $\begin{array}{c}-0.469^{* * *} \\
(0.048)\end{array}$ & $\begin{array}{c}-0.473^{* * *} \\
(0.027)\end{array}$ & $\begin{array}{c}0.769^{* * *} \\
(0.109)\end{array}$ & $\begin{array}{c}0.339^{* * *} \\
(0.060)\end{array}$ & $\begin{array}{c}0.089 \\
(0.060)\end{array}$ & $\begin{array}{c}-0.275^{* * *} \\
(0.033)\end{array}$ & $\begin{array}{c}0.269^{* * *} \\
(0.060)\end{array}$ & $\begin{array}{c}0.641^{* * *} \\
(0.094)\end{array}$ \\
\hline Kids $==1$ & $\begin{array}{c}0.142^{* * *} \\
(0.025)\end{array}$ & $\begin{array}{c}0.489^{* * *} \\
(0.039)\end{array}$ & $\begin{array}{l}-0.017 \\
(0.033)\end{array}$ & $\begin{array}{c}-0.208^{* * *} \\
(0.078)\end{array}$ & $\begin{array}{c}-0.263^{* * *} \\
(0.040)\end{array}$ & $\begin{array}{l}-0.066^{*} \\
(0.035)\end{array}$ & $\begin{array}{c}-0.004 \\
(0.028)\end{array}$ & $\begin{array}{l}-0.060 \\
(0.058)\end{array}$ & $\begin{array}{c}0.461^{* * *} \\
(0.066)\end{array}$ \\
\hline Kids $==2$ & $\begin{array}{c}0.175^{* * *} \\
(0.027)\end{array}$ & $\begin{array}{c}0.374^{* * *} \\
(0.048)\end{array}$ & $\begin{array}{l}-0.012 \\
(0.024)\end{array}$ & $\begin{array}{c}-0.167^{*} \\
(0.096)\end{array}$ & $\begin{array}{c}-0.272^{* * *} \\
(0.046)\end{array}$ & $\begin{array}{c}-0.066^{*} \\
(0.036)\end{array}$ & $\begin{array}{c}0.099^{* * *} \\
(0.038)\end{array}$ & $\begin{array}{c}0.041 \\
(0.091)\end{array}$ & $\begin{array}{c}0.300^{* * *} \\
(0.071)\end{array}$ \\
\hline Age & $\begin{array}{l}-0.001 \\
(0.005)\end{array}$ & $\begin{array}{c}0.007 \\
(0.007)\end{array}$ & $\begin{array}{c}0.007 \\
(0.004)\end{array}$ & $\begin{array}{l}-0.006 \\
(0.010)\end{array}$ & $\begin{array}{l}-0.001 \\
(0.005)\end{array}$ & $\begin{array}{c}0.004 \\
(0.004)\end{array}$ & $\begin{array}{c}0.003 \\
(0.004)\end{array}$ & $\begin{array}{c}0.008 \\
(0.011)\end{array}$ & $\begin{array}{c}-0.037^{* * *} \\
(0.008)\end{array}$ \\
\hline Married & $\begin{array}{c}-0.092^{* * *} \\
(0.014)\end{array}$ & $\begin{array}{c}0.158^{* * *} \\
(0.038)\end{array}$ & $\begin{array}{l}0.045^{*} \\
(0.025)\end{array}$ & $\begin{array}{l}-0.101 \\
(0.064)\end{array}$ & $\begin{array}{c}0.048 \\
(0.048)\end{array}$ & $\begin{array}{c}0.006 \\
(0.030)\end{array}$ & $\begin{array}{c}0.104^{* * *} \\
(0.023)\end{array}$ & $\begin{array}{l}-0.093 \\
(0.112)\end{array}$ & $\begin{array}{c}0.103^{* *} \\
(0.050)\end{array}$ \\
\hline
\end{tabular}




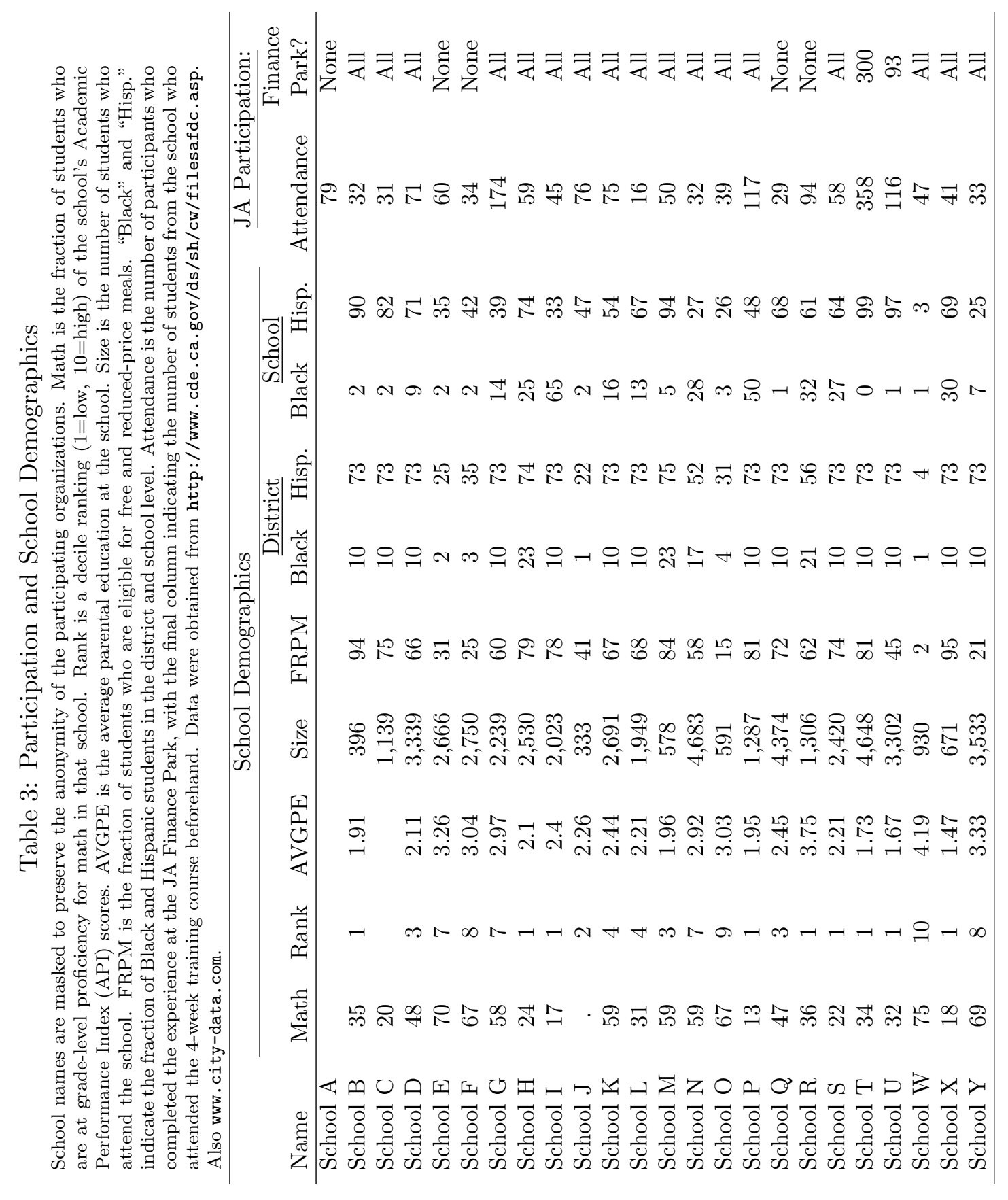


Table 4: Comparing Finance Park to Budget Challenge: Characteristics

This table presents differences in school and district-level characteristics for schools that participated in the Finance Park and Budget Challenge. Students labeled as "Finance Park" students received 24 hours of in-class instruction in financial literacy prior to attending the park, while "Budget Challenge" students did not.

\begin{tabular}{lccc}
\hline Characteristic: & Budget Challenge & Finance Park & $\mathrm{t}($ diff $)$ \\
\hline \% Eligible for FRPM (2007) & 51.36 & 65.61 & -10.39 \\
Parent Education Level & 2.49 & 2.25 & 5.21 \\
\% Black (district) & 6.48 & 10.22 & -10.73 \\
\% Hispanic (district) & 1.18 & 14.00 & -10.56 \\
\% Black (school) & 52.55 & 66.33 & -9.93 \\
\% Hispanic (school) & 66.04 & 64.95 & 0.52 \\
\% White (school) & 25.56 & 8.13 & 14.11 \\
Graduation Rates (2005-2006) & 83.27 & 73.44 & 12.78 \\
Math score & 51.71 & 39.84 & 8.85 \\
Rank score & 4.22 & 3.06 & 5.39
\end{tabular}


Table 5: Comparing Finance Park to Budget Challenge: Choices

This table presents the mean fractions of total net monthly income spent by Budget Challenge and Finance Park students on the 18 different consumer spending categories. Panel A is based on the within-sample comparison of students who went through before and after receiving finance park training; in the pre-treatment column the percentages are based on the amount allocated, rather than net monthly income. Panel B is a comparison of all Budget Challenge versus all Finance Park students. Bank of America is the kiosk associated with home purchase or rental decisions. The size of the home chosen has a direct impact on items 2, 3, and 5, which are gas, electricity, and municipal services, respectively. Item 4 is the choice of telephone package; this includes cell phones and different varieties of land-line packages. Toyota is the kiosk where they make a car purchase decision. Union Bank is a savings account. State Farm is auto and property insurance, and the choice here is largely dictated by the choice in (1) and (6). Providence St. Joseph is health insurance; participants can choose between six plans that vary in terms of the monthly premium and coverage levels (see Table 9). L.A. Valley College is a community college where they can pay for courses that equip them with more marketable skills. Home improvement is mandatory, and is the monthly payment level associated with a home improvement plan they choose. Entertainment, Sport Chalet, and Restaurant each represent opportunities to enjoy movies, sporting equipment purchases, or dining out. Non-profit giving reflects an amount they choose to donate to a local charity.

\begin{tabular}{llcccccc}
\hline & & \multicolumn{3}{c}{ Panel A } & \multicolumn{3}{c}{ Panel B } \\
& Kiosk & Before & After & $\mathrm{t}($ diff $)$ & BC & FP & t(diff) \\
\hline & Completion rate & 0.01 & 0.52 & -8.74 & 0.72 & 0.68 & 1.7 \\
1 & & & & & & \\
2 & Tank Of America & 8.04 & 17.46 & -2.9 & 19.81 & 20 & -1.8 \\
3 & So Cal Edison & 4.85 & 4.41 & 0.17 & 2.18 & 2.19 & -0.09 \\
4 & Phone & 10.26 & 3.44 & 2.82 & 3.21 & 3.23 & -0.35 \\
5 & Water/sewer/trash & 5.78 & 2.64 & 1.25 & 2.31 & 2.22 & 1.3 \\
6 & Toyota & 4.03 & 2.38 & 1.55 & 2.27 & 2.29 & -0.39 \\
7 & Groceries & 5.92 & 13.87 & -3.68 & 16.5 & 16.64 & -1.82 \\
8 & Clothing & 16.45 & 17.21 & -0.17 & 17.13 & 17.19 & -0.74 \\
9 & Union Bank & 11.82 & 4.28 & 3.01 & 4.92 & 5.03 & -1.24 \\
10 & State Farm & 2 & 7.9 & -2.38 & 6.26 & 5.07 & 5.86 \\
11 & Providence St. Joseph & 2.29 & 3.92 & -2.26 & 4.04 & 4.08 & -0.62 \\
12 & La Valley College & 5.21 & 2.72 & 1.18 & 3.12 & 3.12 & 0.15 \\
13 & Home Improvement & 5.66 & 2.11 & 1.44 & 2.25 & 2.3 & -1.58 \\
14 & Entertainment & 2.6 & 4.94 & -2.48 & 4.08 & 4.3 & -2.53 \\
15 & Sport Chalet & 2.21 & 3.58 & -1.58 & 2.61 & 2.8 & -3.2 \\
16 & Restaurant & 4.52 & 2.25 & 1.43 & 1.48 & 1.63 & -3.74 \\
17 & Nonprofit Giving & 2.62 & 1.55 & 0.94 & 1.27 & 1.36 & -2.6 \\
18 & Unlucky Chance Card & 3.45 & 1.63 & 0.76 & 1.3 & 1.53 & -2.27 \\
& & 2.09 & 0.76 & 1.29 & 1.22 & 1.24 & -0.24
\end{tabular}


Table 6: Task completion and financial literacy training This table reports probit regressions in which the dependent variable is a dummy for whether the respondent completed the park experience. Because there is scope for substantial heterogeneity in completion rates based on day-today circumstances, the regressions include school fixed effects, and the standard errors are clustered at the school level. Finance Park is a dummy for whether the students received the financial literacy training course prior to the park experience. All coefficients are reported as marginal changes in probability.

\begin{tabular}{|c|c|c|c|}
\hline & $(1)$ & $(2)$ & $(3)$ \\
\hline Finance Park & $\begin{array}{c}0.366^{*} \\
(0.19)\end{array}$ & $\begin{array}{c}0.369^{* *} \\
(0.19)\end{array}$ & $\begin{array}{c}0.368^{* *} \\
(0.19)\end{array}$ \\
\hline \multicolumn{4}{|c|}{ Profile Characteristics: } \\
\hline Kids $=1$ & & $\begin{array}{l}-0.020 \\
(0.02)\end{array}$ & $\begin{array}{l}-0.020 \\
(0.02)\end{array}$ \\
\hline Kids $=2$ & & $\begin{array}{c}-0.060^{* * *} \\
(0.02)\end{array}$ & $\begin{array}{c}-0.060^{* * *} * \\
(0.02)\end{array}$ \\
\hline Married & & $\begin{array}{c}-0.023^{*} \\
(0.01)\end{array}$ & $\begin{array}{c}-0.028^{*} \\
(0.01)\end{array}$ \\
\hline $\log (\mathrm{NMI})$ & & & $\begin{array}{l}0.021 \\
(0.02)\end{array}$ \\
\hline Income fixed effects & No & Yes & No \\
\hline School fixed effects & Yes & Yes & Yes \\
\hline Observations & 2357 & 2357 & 2357 \\
\hline
\end{tabular}


Table 7: Within-school estimates of the effects of financial literacy training

This table reports Tobit estimations in which each dependent variable is a spending category. School and wealth fixed effects are included, but suppressed. Standard errors are clustered at the school level. Please see Table 5 for descriptions of the spending categories. A total of 1672 observations are included in the regressions.

\begin{tabular}{|c|c|c|c|c|c|c|c|c|c|}
\hline & $\begin{array}{c}\mathrm{B} \text { of } \mathrm{A} \\
(1)\end{array}$ & $\begin{array}{l}\text { Gas Co. } \\
(2)\end{array}$ & $\begin{array}{c}\text { SoCal Ed } \\
(3)\end{array}$ & $\begin{array}{c}\text { Phone } \\
(4)\end{array}$ & $\begin{array}{c}\text { Util. } \\
(5)\end{array}$ & $\begin{array}{l}\text { Toyota } \\
(6)\end{array}$ & $\begin{array}{l}\text { Groc. } \\
(7)\end{array}$ & $\begin{array}{c}\text { Clothing } \\
(8)\end{array}$ & $\begin{array}{c}\text { Union Bank } \\
(9)\end{array}$ \\
\hline Kids $=1$ & $\begin{array}{c}0.442^{* * *} \\
(0.064)\end{array}$ & $\begin{array}{c}0.131^{* * *} \\
(0.027)\end{array}$ & $\begin{array}{l}-0.007 \\
(0.033)\end{array}$ & $\begin{array}{c}-0.135^{* *} \\
(0.060)\end{array}$ & $\begin{array}{c}0.543^{* * *} \\
(0.022)\end{array}$ & $\begin{array}{c}-0.238^{* * *} \\
(0.061)\end{array}$ & $\begin{array}{l}-0.017 \\
(0.066)\end{array}$ & $\begin{array}{c}0.221^{* * *} \\
(0.063)\end{array}$ & $\begin{array}{c}-0.616^{* * *} \\
(0.154)\end{array}$ \\
\hline Kids $=2$ & $\begin{array}{c}1.045^{* * *} \\
(0.124)\end{array}$ & $\begin{array}{c}0.266^{* * *} \\
(0.026)\end{array}$ & $\begin{array}{c}0.105^{* *} \\
(0.046)\end{array}$ & $\begin{array}{c}-0.240^{* * *} \\
(0.073)\end{array}$ & $\begin{array}{c}0.740^{* * * *} \\
(0.031)\end{array}$ & $\begin{array}{c}-0.406 * * * \\
(0.071)\end{array}$ & $\begin{array}{l}0.181^{*} \\
(0.101)\end{array}$ & $\begin{array}{c}0.024 \\
(0.067)\end{array}$ & $\begin{array}{c}-0.650^{* * *} \\
(0.177)\end{array}$ \\
\hline Married & $\begin{array}{c}0.228^{* * *} \\
(0.062)\end{array}$ & $\begin{array}{c}0.035^{* *} \\
(0.018)\end{array}$ & $\begin{array}{c}0.127^{* * *} \\
(0.024)\end{array}$ & $\begin{array}{c}0.039 \\
(0.068)\end{array}$ & $\begin{array}{c}0.402^{* * *} \\
(0.014)\end{array}$ & $\begin{array}{c}-0.106^{* *} \\
(0.044)\end{array}$ & $\begin{array}{c}0.021 \\
(0.062)\end{array}$ & $\begin{array}{l}-0.071 \\
(0.063)\end{array}$ & $\begin{array}{r}-0.321^{*} \\
(0.171)\end{array}$ \\
\hline $\log (\mathrm{NMI})$ & $\begin{array}{c}-1.509^{* * *} \\
(0.100)\end{array}$ & $\begin{array}{c}-1.783^{* * *} \\
(0.046)\end{array}$ & $\begin{array}{c}-0.329^{* * * *} \\
(0.058)\end{array}$ & $\begin{array}{l}-0.068 \\
(0.070)\end{array}$ & $\begin{array}{c}-2.381^{* * * *} \\
(0.049)\end{array}$ & $\begin{array}{c}0.574^{* * *} \\
(0.096)\end{array}$ & $\begin{array}{c}0.917^{* * *} \\
(0.091)\end{array}$ & $\begin{array}{c}0.625^{* * *} \\
(0.129)\end{array}$ & $\begin{array}{c}1.830^{* * * *} \\
(0.321)\end{array}$ \\
\hline
\end{tabular}

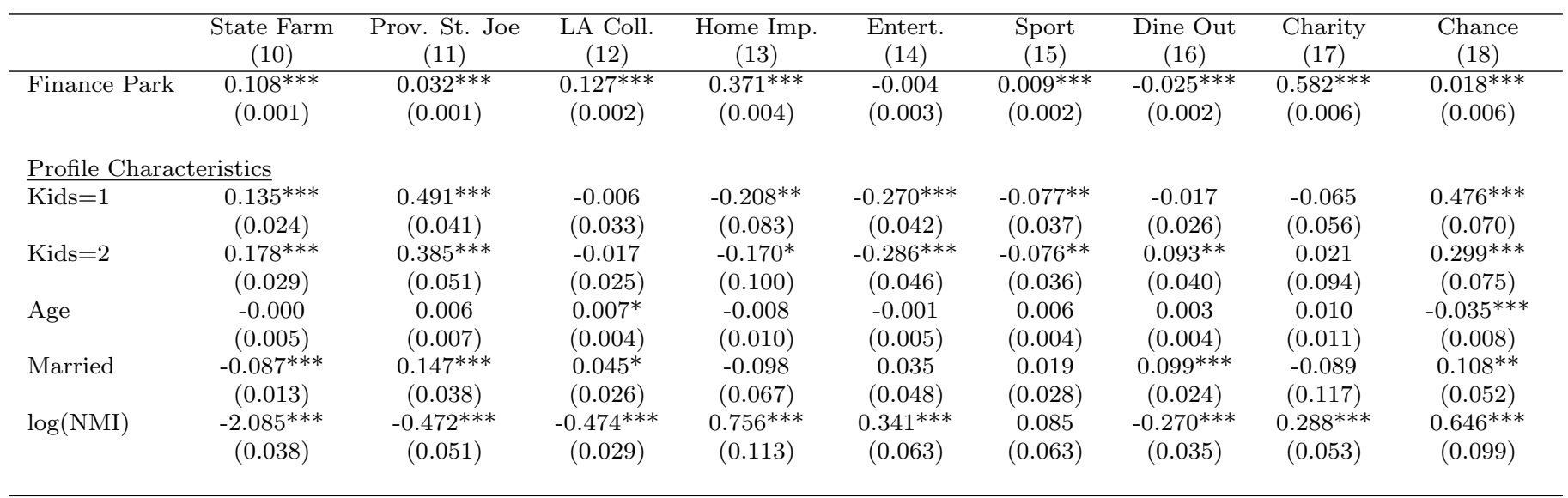


Table 8: Prudent Financial Choices

When students in the park choose an amount to spend on home improvement, they also choose a monthly payment plan. The first three columns report the log of the total interest payments to the total package size. When this variable is smaller, it indicates that the student has chosen to amortize the package more quickly by making larger payments that result in lower overall interest charges. The second three columns report OLS regressions of the log of the ratio of the size of the monthly payment to the total package size. Columns (1), (2), (4) and (5) include school fixed effects. Columns (2), (3), (5) and (6) replace $\log (\mathrm{NMI})$ with income fixed effects.

\begin{tabular}{|c|c|c|c|c|c|c|}
\hline & \multicolumn{3}{|c|}{ Interest: } & \multicolumn{3}{|c|}{ Amortization: } \\
\hline & (1) & $(2)$ & $(3)$ & (4) & $(5)$ & (6) \\
\hline \multicolumn{7}{|c|}{ Personal characteristics } \\
\hline \multirow[t]{2}{*}{ Male } & 0.056 & $0.055^{*}$ & $0.057^{*}$ & -0.039 & $-0.039^{*}$ & $-0.041^{*}$ \\
\hline & $(0.04)$ & $(0.03)$ & $(0.03)$ & $(0.03)$ & $(0.02)$ & $(0.02)$ \\
\hline \multirow[t]{2}{*}{ Hispanic } & -0.044 & $-0.056^{*}$ & -0.049 & 0.030 & 0.038 & 0.033 \\
\hline & $(0.04)$ & $(0.03)$ & $(0.03)$ & $(0.03)$ & $(0.02)$ & $(0.02)$ \\
\hline \multicolumn{7}{|c|}{ Profile characteristics } \\
\hline \multirow[t]{2}{*}{$\log (\mathrm{NMI})$} & $0.825^{* * *}$ & & & $-0.615^{* * *}$ & & \\
\hline & $(0.04)$ & & & $(0.03)$ & & \\
\hline \multirow[t]{2}{*}{ Kids $=1$} & $0.087^{* *}$ & 0.055 & 0.051 & $-0.062^{*}$ & $-0.048^{*}$ & -0.045 \\
\hline & $(0.04)$ & $(0.03)$ & $(0.03)$ & $(0.03)$ & $(0.03)$ & $(0.03)$ \\
\hline \multirow[t]{2}{*}{ Kids $=2$} & -0.008 & 0.017 & 0.007 & 0.009 & -0.023 & -0.016 \\
\hline & $(0.04)$ & $(0.04)$ & $(0.04)$ & $(0.03)$ & $(0.03)$ & $(0.03)$ \\
\hline \multirow[t]{2}{*}{ Age } & $-0.012^{* *}$ & 0.003 & 0.002 & $0.007^{* *}$ & -0.002 & -0.002 \\
\hline & $(0.00)$ & $(0.00)$ & $(0.00)$ & $(0.00)$ & $(0.00)$ & $(0.00)$ \\
\hline \multirow[t]{2}{*}{ Married } & $0.069^{* *}$ & 0.025 & 0.027 & $-0.070^{* * *}$ & -0.028 & $-0.029^{*}$ \\
\hline & $(0.03)$ & $(0.02)$ & $(0.02)$ & $(0.02)$ & $(0.02)$ & $(0.02)$ \\
\hline \multirow[t]{2}{*}{ Finance Park } & $-0.063^{* *}$ & $-0.099 * * *$ & $-0.061^{*}$ & $0.049^{* * *}$ & $0.078^{* * *}$ & $0.047^{*}$ \\
\hline & $(0.03)$ & $(0.01)$ & $(0.03)$ & $(0.01)$ & $(0.00)$ & $(0.03)$ \\
\hline \multicolumn{7}{|c|}{ School characteristics } \\
\hline \multirow[t]{2}{*}{ Parent Ed. Level } & & & -0.086 & & & 0.058 \\
\hline & & & $(0.06)$ & & & $(0.05)$ \\
\hline \multirow[t]{2}{*}{ Math score } & & & -0.003 & & & 0.002 \\
\hline & & & $(0.00)$ & & & $(0.00)$ \\
\hline \multirow[t]{2}{*}{ Black (district) } & & & $-0.009^{* * *}$ & & & $0.007^{* *}$ \\
\hline & & & $(0.00)$ & & & $(0.00)$ \\
\hline \multirow[t]{2}{*}{ Hispanic (district) } & & & -0.001 & & & 0.001 \\
\hline & & & $(0.00)$ & & & $(0.00)$ \\
\hline \multirow[t]{2}{*}{ Black (school) } & & & 0.000 & & & -0.001 \\
\hline & & & $(0.00)$ & & & $(0.00)$ \\
\hline \multirow[t]{2}{*}{ Hispanic (school) } & & & 0.002 & & & -0.002 \\
\hline & & & $(0.00)$ & & & $(0.00)$ \\
\hline \multirow[t]{2}{*}{ Rank score } & & & $0.045^{*}$ & & & -0.035 \\
\hline & & & $(0.02)$ & & & $(0.02)$ \\
\hline \multirow[t]{2}{*}{ FRPM } & & & 0.001 & & & -0.001 \\
\hline & & & $(0.00)$ & & & $(0.00)$ \\
\hline Observations & 1230 & 1230 & 1207 & 1230 & 1230 & 1207 \\
\hline R-squared & 0.28 & 0.60 & 0.60 & 0.29 & 0.58 & 0.57 \\
\hline
\end{tabular}


Table 9: Health Insurance Behavior

In columns (1)-(3) the dependent variable is a dummy variable that accounts for whether the respondent has a family but does not have insurance that covers the family (i.e., they appear to have chosen individual instead of family insurance). In Columns (4)-(6), the dependent variable is a dummy for whether the person chose a plan with high premiums that has fixed-payment copays ( $\$ 15$ per visit) versus lower premiums with percentage copay ( $15 \%$ of cost).

\begin{tabular}{|c|c|c|c|c|c|c|}
\hline & \multicolumn{3}{|c|}{ Underinsured: } & \multicolumn{3}{|c|}{ Flat-fee Copay: } \\
\hline & (1) & (2) & (3) & (4) & (5) & (6) \\
\hline \multicolumn{7}{|c|}{ Personal characteristics } \\
\hline Male & $\begin{array}{l}0.006 \\
(0.01)\end{array}$ & $\begin{array}{l}0.005 \\
(0.01)\end{array}$ & $\begin{array}{l}0.005 \\
(0.01)\end{array}$ & $\begin{array}{c}0.055^{* *} \\
(0.03)\end{array}$ & $\begin{array}{c}0.046^{*} \\
(0.03)\end{array}$ & $\begin{array}{c}0.056^{* *} \\
(0.03)\end{array}$ \\
\hline Hispanic & $\begin{array}{l}0.010 \\
(0.01)\end{array}$ & $\begin{array}{l}0.007 \\
(0.01)\end{array}$ & $\begin{array}{l}0.007 \\
(0.01)\end{array}$ & $\begin{array}{l}-0.024 \\
(0.03)\end{array}$ & $\begin{array}{l}-0.026 \\
(0.03)\end{array}$ & $\begin{array}{l}-0.020 \\
(0.03)\end{array}$ \\
\hline \multicolumn{7}{|c|}{ Profile characteristics } \\
\hline $\log (\mathrm{NMI})$ & $\begin{array}{c}-0.015^{*} \\
(0.01)\end{array}$ & & & $\begin{array}{c}0.856^{* * *} \\
(0.04)\end{array}$ & & \\
\hline Kids $=1$ & $\begin{array}{l}0.013 \\
(0.01)\end{array}$ & $\begin{array}{l}0.000 \\
(0.01)\end{array}$ & $\begin{array}{l}0.001 \\
(0.01)\end{array}$ & $\begin{array}{c}-0.189^{* * *} \\
(0.04)\end{array}$ & $\begin{array}{c}-0.247^{* * *} \\
(0.05)\end{array}$ & $\begin{array}{c}-0.243^{* * *} \\
(0.05)\end{array}$ \\
\hline Kids $=2$ & $\begin{array}{l}0.002 \\
(0.01)\end{array}$ & $\begin{array}{c}-0.012^{* *} \\
(0.01)\end{array}$ & $\begin{array}{c}-0.011^{* *} \\
(0.01)\end{array}$ & $\begin{array}{c}-0.099^{* * *} \\
(0.03)\end{array}$ & $\begin{array}{c}-0.168^{* * *} \\
(0.04)\end{array}$ & $\begin{array}{c}-0.162^{* * *} \\
(0.04)\end{array}$ \\
\hline Age (profile) & $\begin{array}{l}-0.000 \\
(0.00)\end{array}$ & $\begin{array}{l}0.000 \\
(0.00)\end{array}$ & $\begin{array}{l}0.000 \\
(0.00)\end{array}$ & $\begin{array}{l}-0.003 \\
(0.00)\end{array}$ & $\begin{array}{r}-0.008 \\
(0.01)\end{array}$ & $\begin{array}{c}-0.007 \\
(0.01)\end{array}$ \\
\hline Married (profile) & $\begin{array}{l}0.011 \\
(0.01)\end{array}$ & $\begin{array}{c}0.018^{* *} \\
(0.01)\end{array}$ & $\begin{array}{c}0.016^{* *} \\
(0.01)\end{array}$ & $\begin{array}{c}-0.257^{* * *} \\
(0.02)\end{array}$ & $\begin{array}{c}-0.222^{* * * *} \\
(0.02)\end{array}$ & $\begin{array}{c}-0.221^{* * *} \\
\quad(0.02)\end{array}$ \\
\hline Finance Park & $\begin{array}{l}-0.002 \\
(0.01)\end{array}$ & $\begin{array}{l}-0.001 \\
(0.01)\end{array}$ & $\begin{array}{l}0.001 \\
(0.01)\end{array}$ & $\begin{array}{c}-0.183^{* * *} \\
(0.01)\end{array}$ & $\begin{array}{c}-0.196^{* * *} \\
(0.01)\end{array}$ & $\begin{array}{c}-0.101^{* *} \\
(0.05)\end{array}$ \\
\hline \multicolumn{7}{|c|}{$\underline{\text { School characteristics }}$} \\
\hline Parent Ed. Level & & & $\begin{array}{c}-0.022^{*} \\
(0.01)\end{array}$ & & & $\begin{array}{l}-0.049 \\
(0.07)\end{array}$ \\
\hline Math score & & & $\begin{array}{l}0.001 \\
(0.00)\end{array}$ & & & $\begin{array}{l}0.001 \\
(0.00)\end{array}$ \\
\hline Black (district) & & & $\begin{array}{c}-0.003^{* *} \\
(0.00)\end{array}$ & & & $\begin{array}{c}0.008^{* * *} \\
(0.00)\end{array}$ \\
\hline Hisp (district) & & & $\begin{array}{l}0.000 \\
(0.00)\end{array}$ & & & $\begin{array}{l}0.002^{*} \\
(0.00)\end{array}$ \\
\hline Black (school) & & & $\begin{array}{l}0.001^{*} \\
(0.00)\end{array}$ & & & $\begin{array}{l}-0.001 \\
(0.00)\end{array}$ \\
\hline Hispanic (school) & & & $\begin{array}{l}0.001^{*} \\
(0.00)\end{array}$ & & & $\begin{array}{l}-0.002 \\
(0.00)\end{array}$ \\
\hline School rank & & & $\begin{array}{c}0.008^{* *} \\
(0.00)\end{array}$ & & & $\begin{array}{l}-0.028 \\
(0.02)\end{array}$ \\
\hline FRPM & & & $\begin{array}{l}-0.000 \\
(0.00)\end{array}$ & & & $\begin{array}{c}-0.003^{* * *} \\
(0.00)\end{array}$ \\
\hline School Effects & Yes & Yes & No & Yes & Yes & No \\
\hline Wealth Effects & No & Yes & Yes & No & Yes & Yes \\
\hline Observations & 1021 & 1021 & 1207 & 1230 & 1230 & 1207 \\
\hline
\end{tabular}




\section{A. Junior Achievement Finance Park Program Summary}

JA Finance Park offers students personal financial management and career exploration through classroom instruction and active participation in a simulated community. The curriculum is designed as an integrated unit, preparing students for an all-day visit to JA Finance Park.

The learning objectives listed beside each activity state the skills and knowledge the students will gain.

\section{A. Activity One - Financial Institutions:}

Students recognize the role of financial institutions and the various services they provide. Through case study, graphing and other activities, students understand the advantages and disadvantages of saving, investing and using credit. Key Learning Objectives Students will be able to:

- identify services provided by financial institutions and understand how/when the services are used

- explain debit cards and their uses define interest and credit

- understand the cost of credit

- explain the advantages and disadvantages of using credit

- list the risks and benefits involved in saving and investing

- identify the impact interest rates have on investment value

- read stock quotes and determine stock value

\section{B. Activity Two - Taxes and My Salary:}

Students discuss the similarities and differences among sales, income, and property taxes. Students study the benefits and limitations of Social Security. Using various scenarios, students determine net monthly income (NMI).

Key Learning Objectives Students will be able to:

- define the differences among sales, income, and property taxes and the purpose of each 
- identify the basic principles of Social Security

- define NMI and demonstrate how it is calculated

\section{Activity Three - Budgeting:}

Students learn the importance of creating and maintaining a personal budget. Students create their own personal budgets and evaluate other budgets through case study analysis.

Key Learning Objectives Students will be able to:

- understand who uses a budget and why

- identify the components of a successful budget

- evaluate the effectiveness of sample budgets

- develop spending plans and practice making budget decisions

\section{Activity Four - Preparing for the Visit:}

Students prepare for their visit to JA Finance Park by defining their schedule, conducting pricing research, and assessing investment. They also gain knowledge about budgeting by evaluating hypothetical life situations and prioritizing budget items.

Key Learning Objectives Students will be able to:

- create a personal budget

- calculate net monthly income

- conduct pricing research and assess investments

E. Activity Five - The Visit:

Students spend one day at JA Finance Park where they apply classroom learning by making important spending decisions and maintaining a balanced budget.

Key Learning Objectives Students will be able to:

- create a typical family budget using hypothetical life situations

- use percentages to calculate minimum and maximum spending allowances

- evaluate stock holdings 


\section{F. Activity Six - After the Visit:}

Students participate in a reflective assessment of their accomplishments during their visit to JA Finance Park that includes feedback from parents.

Key Learning Objectives Students will be able to:

- demonstrate integration of classroom instruction to the simulation experience

- perform a credit card and investment assessment

- conduct self-reflection regarding their visit

\section{G. Activity Seven - Career Goals (optional activity):}

Students identify their abilities, interests, work preferences, and values. Based on their newly acquired financial knowledge, students consider the type of lifestyle they would like and what goals they must set to achieve this lifestyle. Students determine the training they will need to achieve these goals.

Key Learning Objectives Students will be able to:

- differentiate between abilities, interests, work preferences, and values

- identify their personal characteristics

- rate their abilities, interests and work preferences

- identify their career interests

- perform career choice research

- write a letter of application to a prospective employer

\section{JA Finance Park enhances the students learning of the following concepts and skills:}

Concepts Banking Budgets Buying Careers Choices Consumers Credit Debt Exchange Expenses Income Interest rates Investments Money Opportunity costs Saving Scarcity Spending Social security Standards of living Taxes 
Skills Analysis Applying information Budgeting Cause and effect Critical thinking Computation Data collection Decision making Filling out forms Following directions Graphing Interpersonal communication Interpreting data Listening Negotiation Observation Planning Problem solving Reading Research Role playing Taking responsibility Teamwork

All JA programs have technology enhancements and are designed to support the skills and competencies outlined in the SCANS (Secretarys Commission on Achieving Necessary Skills) report. These programs also augment the school-based, work-based, and connecting activities for communities with school-to-work initiatives. 